\title{
COMMUNICATION PLANNING AND POLICY: COMMUNICATION PLANNING PT. ABADI LIGHT TELEVISION (TATV) BRANDING
}

\author{
Ibrahim T.I. Ukka ${ }^{1}$ \\ ${ }^{1}$ School of Journalism and information Communication, \\ Huazhong University of Science and Technology, Wuhan, China.
}

*Corresponding Author: Ibrahim T.I. Ukka

Corresponding Author Email: ibrahimokah@ hust.edu.cn

Article Received: 09-06-19 Accepted: 15-07-19

Published: 05-08-19

Licensing Details: Author retains the right of this article. The article is distributed under the terms of the Creative Commons Attribution-NonCommercial 4.0 License (http://www.creativecommons.org/licences/by-nc/4.0/) which permits non-commercial use, reproduction and distribution of the work without further permission provided the original work is attributed as specified on the Journal open access page.

\section{ABSTRACT}

The presence of PT. Eternal Light Television (TATV) as local television in Surakarta and surrounding there initially, viewed pessimistically by the surrounding community. This is very reasonable considering that no television has been established in Surakarta. On April 29, 2004, TATV began broadcasting on air, and was called "Jelang Tayang Perdana". At the start of launching on air or the trial broadcast by TATV it still seemed to be less professional. There are no programs that can be presented such as national television, only limited to advertisements in the form of slides. The screenings are still very simple and not very interesting. In addition to image quality, it may be due to the lack of human resource management.

At first, TATV only broadcast for 3 hours and the ShowTime is still limited to daylight hours. After conducting a grand launch on September 1, 2004, TATV began broadcasting for 8 hours per day. After surviving several months with broadcasts for 8 hours per day in subsequent developments, TATV then began pursuing the target to be 14 hours per day. And 
the current situation of TATV has had broadcast hours of 18 hours per day which continue to the present day. TATV has a strong commitment to fight for the creation of an advanced Indonesian society in all aspects of life, based on positive life values. This commitment is communicated by TATV management, to viewers via TV PROMO, Content (Program on air), or through continuous (intense) event affair. The aim is to create a single perception that is strong in the minds of viewers.

Keywords: Communication Planning and Policy, organizational structure, abadi light television

\section{Environmental Analysis}

\section{INTRODUCTION}

Television broadcasts require huge costs and human resources in large quantities as well. Deficiencies in these two things will greatly affect the quality of broadcasts and program shows. Although the category of local television stations, however, the presence of TATV means that it has it shows good development for the city of Surakarta and allows other cities around it. In subsequent developments as management improved, the concept of TATV as local television began to appear. By not ignoring its shortcomings, TATV seems to have succeeded in carrying out the concept of Javanese culture. This character is very clearly seen from various programs that carry Javanese culture in full, such as Javanese news, discussions about Javanese culture, campursari and so on.

The efforts of the Jakarta S City that compare itself with the Spirit of Java strongly correlate with the fate of TATV life going forward. If TATV management is able to continue to oversee and even strengthen or expand the branding area of Jakarta City, it is very possible that TATV will become a popular television in Central Java and Yogyakarta. In other words, branding for TATV must also accompany the branding carried out for Surakarta City. TATV branding must be able to work together and collaborate with the Surakarta City government. With this, all changes and developments in the city of Surakarta itself can be seen from the news and series of programs aired by TATV. A LOGO for a company can mean a lot: image, ideals, passion and blessing

\section{SWOT Analysis}

In the SWOT analysis the components used relate to important factors for the company and relate to the company's future which consists of strengths, weaknesses, opportunities and Threats .

\section{Strength}

1. The only local television in Surakarta that received legal permission from KPI. In Central Java there is a lot of local television, but there are only 3 televisions that get legal permission from the Indonesian government, one of which is TATV .

2. Local cultural content that brings him closer to the masses with the community, especially in Surakarta City and the surrounding area. 


\section{Weakness}

1. Many thoughts from outside communities that TATV is only a community television, even though this is not true.

2. Technology limitations compared to television with national reach

3. S urakarta is not a research area, therefore research exposures are lacking

\section{Opportunity}

1. Government regulation to front requires the existence of networked television, so that local content can be elevated and there is no centralization in certain areas. This encourages the chances of developing TATV as local media.

2. The amount of opportunity for segmentation of the people who want local content

3. The number of Communication Studies Departments in Surakarta is a stock of HR for TATV

\section{Threat}

1. Competition with national television has more capital and more and more professional human resources.

\section{Goal Setting}

Objectives are statements about an issue and a description of how to achieve the desired expectations. The aim of a program includes two levels, namely long-term goals and short term.

1. Long-term goal : TATV brand and brand are formed as a television that is cultured to the public.

2. Short term goals : awareness of the people about the new TATV brand and logo is formed .

\section{Objective Determination}

Goals must be clearly stated and measurable. By concentrating the target at the objective $\mathrm{f}$ public communication program are:

- Effects awareness, to increase knowledge of the target audience will a decent existence and also change the logo TATV

- Effects acceptance, to foster positive affection a target worthy of TATV

- An action effect, increasing the interest of the target audience to watch TATV at least one program in a day

\section{Determination of Audiences}

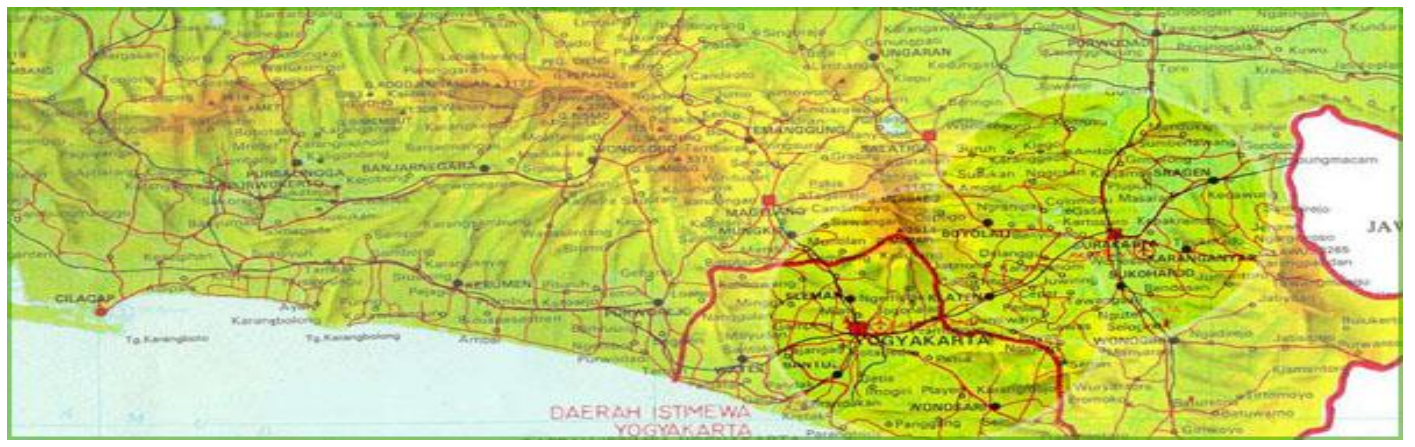




\section{Area Coverage:}

1. Magelang Regency, Regency Salatiga, Regency Temanggung

2. Surakarta

(Solo), District of Klaten, Boyolali, Wonogiri, Sukoharjo, Karanganyar, and

District Klaten

3. districts Pati, Regency Kudus, Regency Wonosobo

Table 1

\begin{tabular}{|c|c|c|c|}
\hline Region & Man & Women & total \\
\hline Kab. Wonosobo & 404,464 & 364,674 & 769,138 \\
\hline Kab. Magelang & 591,211 & 563,750 & $1,154,951$ \\
\hline Magelang City & 58,767 & 64,809 & 123,576 \\
\hline Surakarta City & 247,247 & 257,906 & 505,153 \\
\hline Kab. Boyolali & 469,578 & 462,372 & 931,950 \\
\hline Kab. Sukoharjo & 405,526 & 415,159 & 820,685 \\
\hline Kab. Karanganyar & 418,176 & 402.256 & 820,432 \\
\hline Kab. Wonogiri & 489,528 & 517,907 & $1,007,435$ \\
\hline Kab. Sragen & 417,272 & 445,774 & 863,046 \\
\hline Kab. Klaten & 558,552 & 569,195 & $1,127,747$ \\
\hline Kab. Starch & 574,811 & 623,045 & $1,197,856$ \\
\hline Kab. Holy & 369,951 & 375,897 & 745,848 \\
\hline Ngawi & 426,615 & 446,884 & 873,489 \\
\hline total & $3,005,879$ & $3,070,569$ & $6,075,448$ \\
\hline
\end{tabular}

Population Composition of the Special Region of Yogyakarta

Table 2

BPS YOGYAKARTA

\begin{tabular}{llll}
\hline Region & Man & Woman & Total \\
\hline Yogyakarta city & 267,496 & 253,284 & 520,780 \\
Kab. Bantul & 398,975 & 414,077 & 813,052 \\
Kab. Kulon Progo & 223,613 & 234,165 & 457,778 \\
Kab. Gunung Kidul & 371,285 & 388,843 & 760,128 \\
Kab. Sleman & 449,673 & 458,021 & 907,694 \\
\hline
\end{tabular}




\begin{tabular}{llll}
\hline total & $1,711,042$ & $1,748,390$ & $3,459,432$ \\
\hline
\end{tabular}

\section{Project Vision and Mission}

\section{Project vision:}

TATV's image was built as a local television that is cultured but still follows the era

Project mission:

Bringing brand through promotion and program programs by bringing Javanese cultural characters

\section{Strategic / tactical planning}

The strategy used in the planning of this communication program is a strategic proactive. The meaning of proactive strategies, namely communication strategies that arise at the initiative of the organization in accordance with the organization's plan. That strategy used in communication programs this includes:

a. Organizational Performances, convincing the public that TATV presents quality broadcast programs, in accordance with the character of Javanese culture and supported by quality resources.

b. Audience Participation, giving audiences the opportunity to give feedback on messages that have been delivered in order to do outside in i, for example by holding a survey to find out the opinion of a decent kh about programs and performance TATV.

c. special events, for example by holding various types of competitions that are fully sponsored by TATV or with other companies.

d. Alliances and coalitions, for example by collaborating with government, universities, schools, communities and various other institutions to create an event program .

\section{Location}

\section{LOCATION DESCRIPTION}

TATV began on September 1, 2002 in Surakarta. However, it was established on July 1, 2003. The permit officially aired on September 1, 2004 based on the Decree of the Governor of Central Java No. 483/129/2003. In the aim of its establishment, TATV wishes to participate in realizing the vision and mission of Surakarta City, keep maintaining the repertoire of the environment, broaden its horizons, and contribute to improving the moral, educational, cultural and social welfare within the framework of the Republic of Indonesia with modern mass media. (Source: TATV)

By not forgetting responsibility as a messenger, TATV sees the importance of a good influence for the better life of the Indonesian people as consumers of TV programs / programs. TATV feels the need to give different colors to each product program by putting forward positive things. As an information agent, TATV has an ideal to provide various impacts for the development and progress of the people of Central Java and DIY in particular and Indonesia in general.

Location of TATV studios built on land on Jl. Brig. Gen. Katamso 173 Mojosong Surakarta. Has broadcast hours of 18 hours per day from $06.00-24.00$. TATV has a coverage area covering all 
ex- S Residency urakarta (SUBOSUKAWONOSRATEN), including Surakarta, Boyolali, Karanganyar, Sukoharjo, Wonogiri, Sragen and Klaten, including Jogjakarta and its surroundings. In the future, TATV will try to reach the broadcast area to Semarang and surrounding areas.

\section{Vision}

Being a television that gives enlightenment to the paradigm of thinking and behaving for viewers and society, towards the development of Indonesian people as a whole.

\section{Mission}

Providing meaningful contributions for the advancement of the region and the viewing community in all areas of life, through paradigm shifts in thinking and behaving.

\section{Table 3}

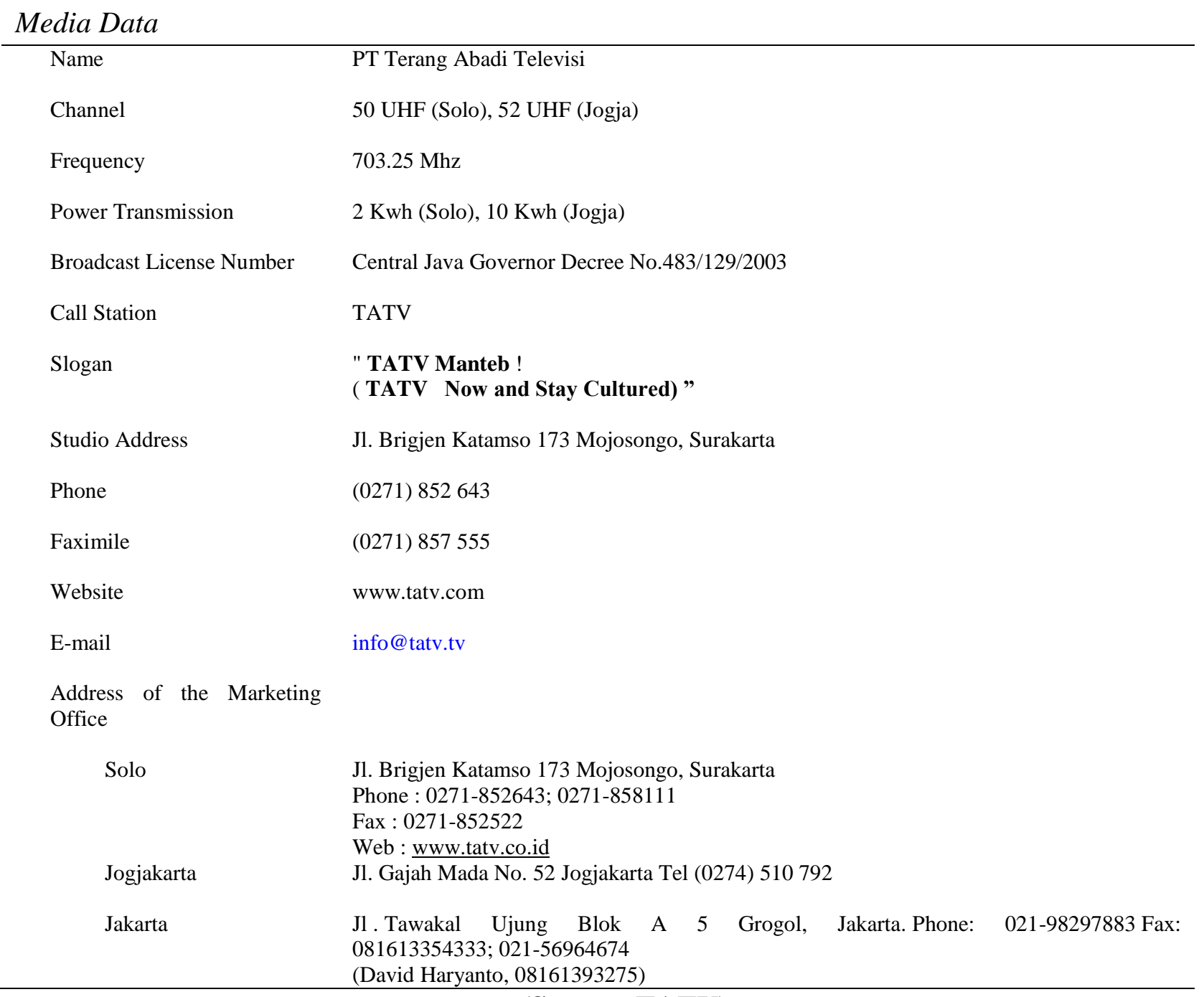

(Source: TATV) 
Table 4

Target and Segmentation

Gender

Male and Female

Age

Primary 15-50 + years old

Children 5-15 years old

Tertiary adult $25+$

Family lifecycle

Single and Married

Occupation

Student, Housewife, professional, entrepreneur, Executive, Laboers and Not worked

Social class

All class (A, B, C, D, E)

Lifestyle

Traditional and Modern

Personality

Friendly, Energitic and Goodmanners

Innovativeness

Early Adopter.

(Source: TATV)

\section{PROGRAM COMPOSITION}

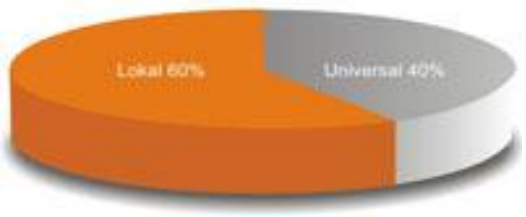

\section{Content Program}

Lokal 60\%, Universal 40\%

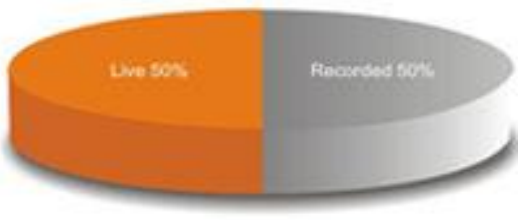

Broadcast Format

Live 50\%, Recorded 50\%

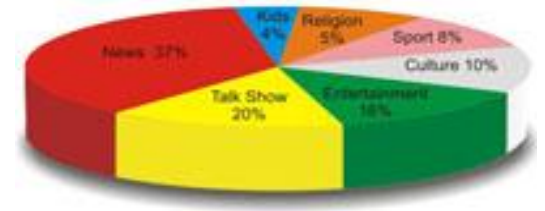

Program Composition

News 37\%, Talk Show 20\%, Entertainment 16\%, Culture 10\%, Sport 8\%, Religion 5\%, Kids $4 \%$.

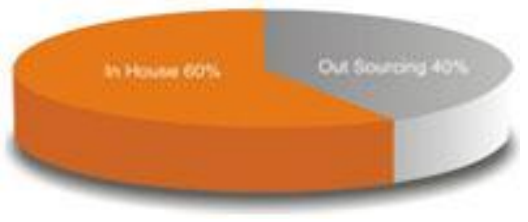

Program Source

In House 60\%, Out Sourcing 40\% 

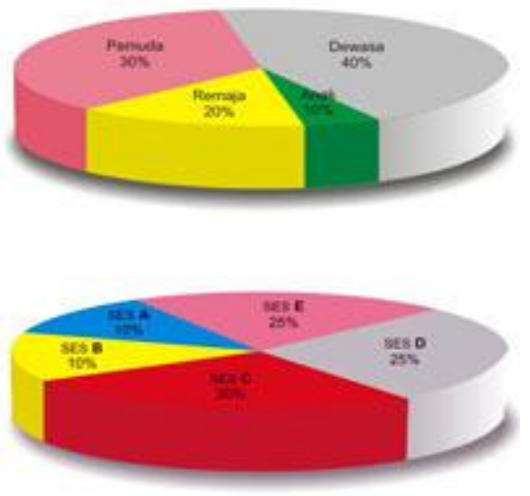

\author{
SES Based Audience Classification (Social Economic \\ Status) \\ SES A $10 \%$, SES B 10\%, SES C 30\%, SES D 25\%, SES \\ E $25 \%$
}

\section{TAT V LOGO}

\section{Logo first}

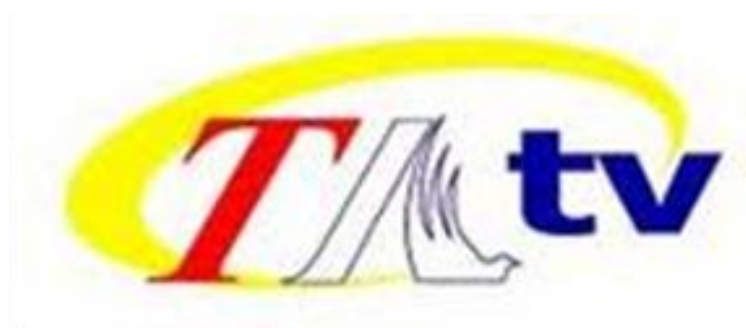

\section{Logo now}

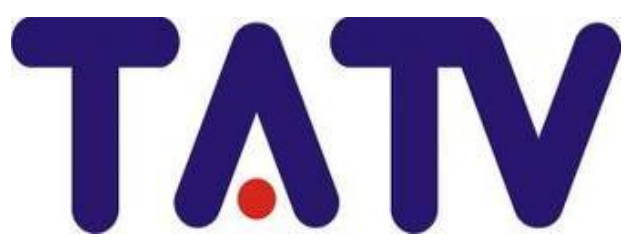

(Source: TATV)

\section{ORGANIZATIONAL STRUCTURE OF PT TERANG ABADI TELEVISION (TATV)}

TATV's organizational structure is divided into 3 main divisions, whose position is under the leadership / President Director, namely the news division, marketing division, and operational division.

\section{Planning}

\section{WORK THEORY}

Planning is setting goals to be achieved or to be done, how, when and by whom. In the book, Planning for Economic Development explained that the plan is: "A plan Provides 
guidelines for $p$ o licy through the translation of Reviews These general objectives into physical targets and specific tools for particular economic and social activities".

Therefore, planning is a continuous process, which includes the plan, and implementation, which continually needs to have elements:

a) Having characteristics that are oriented towards implementation in the future.

b) Process that is continuity and flexibility.

c) Seeking planning can be as operational as possible in achieving the goal.

d) The existence of a reporting and evaluation system in the planning process.

Planning in an activity is very important, because planning helps supervision in every program implementation (Anne Gregory, 2003: 49-50) . A plan is the first step in an effort to achieve an activity.Walaupu $n$ various definitions of the different plans, but experts agree agree that planning is essentially a conscious effort and continuous and organized to select the best of the various alternatives that exist for achieving a specific goal.

Planning can also be understood as a written statement about everything that will or should be done. The nature of planning is always oriented to the future (future oriented). Communication planning is a written statement about a series of actions about how a communication activity will or must be done in order to achieve behavior change in accordance with what we want.

Understood there are four (4) main elements of Planning, namely:

- Objective (Objective). Future conditions to be achieved.

- Action (Action). A series of activities carried out to achieve the goal.

- Resources (Resources ). Things that are needed in carrying out the action.

- Implementation ( Implementation ). Procedure and direction of implementation of activities. In the planning process, the impact or effect produced depends on the four elements of planning. In the planning process, the role of communication is e rampilan ket is important to be owned by the manager (Anne Gregory, 2003: 21-22). Therefore, it can be said also that communication planning includes management functions, namely:

1. Plotting (Planning).

2. Held (Organizing).

3. Prioritizing (Leading).

4. Supervise (Controlling).

The stages of communication planning basically consist of: (1) the stage of identifying communication problems, (2) the stage of formulating communication objectives, (3) the stage of strategic planning, (4) the stage of the operational plan, (5) the evaluation plan preparation stage, and (6) the stage of planning recommendations. These stages must be carried out one by one in sequence, may not jump up and down. In the problem identification stage, it is necessary to collect data / facts / information about the condition of the audience as material for analyzing the audience. The formulation of the problem must be based on the felt needs and real needs of the target audience. 
The purpose of communication is a goal that involves efforts to change target behavior after communication activities are carried out. The formulation of objectives must include: the target audience, the scope of the target number, and the desired behavior change. The operational plan is a conceptual description of the resources needed in the implementation of a program or project. Determination of strategic plans contains elements of $5 \mathrm{M}$, namely: Man, Messages, Media, Money, and Means. The operational plan is a detailed and systematic description of the planned activities to be carried out in the implementation of the program, concerning the allocation of time for the implementation of activities, and the relationship between activities. The evaluation plan is a plan for how to evaluate the program, which can be process evaluation, outcome evaluation, and program impact evaluation. The recommendation plan is a plan regarding recommendations or recommendations that will be submitted in accordance with the evaluation plan to obtain input for the improvement and development of the program.

\section{Strategic Communication Planning}

Strategic planning is the process of developing and maintaining a strategic match between the goals and capabilities of an institution with changing marketing opportunities. This planning relies on developing a clear institutional mission, supporting goals and objectives, the right strategy, and the right implementation.

That definition shows the steps that can be taken an educational institution to improve his effectiveness. First, the institution must analyze its current and future environment. Second, the agency reviews its main sources to propose what can be done. Third, the institution sets its overall goals and specific objectives. Fourth, the agency reviews its mission and selects the most effective strategy the costs for achieving these goals and objectives. Fifth or last one, implementation these strategies usually require change - change in the institutional structure and information systems, planning and control at the agency. When these components are put together, they promise improved performance.

Smith (2005) provides nine phases grouped into four phases in strategic communication for public relations namely formative research, strategy, tactic and evaluation research. The following is marketing communication planning using the phases proposed by Smith.

a. Formative Research

The first phase in the strategic planning process according to Smith is formative research or strategic research is a preliminary activity carried out to obtain information and analyze the situation at hand (Smith, 2005: 11). In this phase, there are three stages, namely situation analysis, organizational analysis and public analysis.

Situation is a set of conditions faced by an organization. Situations have identical meanings and problems. So that situation analysis is a statement about the opportunities and obstacles faced by communication programs. Without a clear and early statement of the situation being faced, research efficiency cannot be carried out. This situation definition is expressed in the form of a noun. Whereas those included in the analysis of the organization include aspects of the internal environment, public perceptions and the external environment faced including competitors and 
supporters. Whereas public analysis is the identification and analysis of key public-public from various groups of people who interact with the organization.

\section{b. Strategy}

After formative research, the second phase is strategy. Strategy is the heart of the planning of public relations and marketing communications and other related fields. Strategy is the overall plan of the organization, including what you want to achieve and how to achieve it. The strategy has two focuses, namely the actions taken by the organization and the contents of the message. The strategy has three stages, namely setting goals and objectives, formulating actions and response strategies, then using effective communication.

Objectives are statements about an issue and a description of how to achieve the desired expectations. The purpose of communication can be grouped into three categories, namely reputation management goals, which relate to the identity and perception of the organization, relationship management goals related to organizational relations with the public and task management goals related to how to do something.

\section{c. Tactic}

After the strategy is made, it is now the turn to enter the third phase, namely tactics. In this phase it consists of selecting communication tactics that will be used and implementing the strategic plan that has been prepared. The communication tactics used in marketing communications planning are a combination of public relations and marketing communications activities commonly referred to as integrated communication.

\section{d. Evaluative Research}

In planning communication begins with research and ends with research as well. Research carried out in the last phase was to determine the effectiveness of various communication tactics used to achieve the goals and objectives that have been determined. The method that can be used to evaluate the effectiveness of tactics in achieving goals is to use the After-Only study design. Such designs are the most common and easy to measure attitudes. While the methodology for evaluation techniques is quantitative techniques, namely conducting surveys, analyzing content on news or mass media publications.

\section{Company identity}

Identity is associated as "the way in which companies present themselves to their target groups." Corporate identity or corporate identity comes from words synonymous with logos, company house style and other forms of symbols used by the organization. The concept is now increasingly widespread and comprehensive to indicate the efforts by which the company presents itself using symbols, communication and behavior.

The company's self-presentation can be developed in the following ways:

1. Behavior. The effective and most important medium through corporate identity is created by the behavior of the company. The target group will assess the company for what it 
does. However, it is not possible to emphasize specific aspects of corporate behavior through communication and / or symbolic meanings.

2. Communication. Through rough communication, Birkigt and Stadler interpret it as sending verbal or visual messages. This is the most flexible CI instrument, and can be quickly taken as a real step.

3. Symbolization. According to Birkigt and Stadler, this tool should be harmonious with the expression of corporate identity. He gives an implicit indication of why the company stands and what can be expected from the company.

4. Personality. Described by Birkigt and Stadler as manifestations of the company's selfperception. This implies that the company must know itself well. For Birkigt and Stadler, the company's personality involves his attention and the way in which he reacts to stimuli from his environment.

\section{SWOT Analysis.}

In order to see the company's competitive position based on the results of the analysis of the environment, situation analysis is used. Situation analysis is a way to get a strategic ability between external opportunities and internal strength. The method commonly used in conducting situations is a SWOT analysis. SWOT analysis is a means of assessing external conditions and their application to the company's internal capabilities. In in the SWOT analysis the components used relate to important factors for the company and relate to the company's future . According to Anne Gregory (2003: 62-63) SWOT analysis consists of strengths, weaknesses, opportunities and Threats . The explanation for each component is as follows:

1. Power Analysis (Strengths)

Strength is a special advantage that comes from the company and provides a competitive advantage for companies within an industry, and will support business development. The power to observe sources of funds, image, market leadership, relationships with consumers or suppliers and others.

2. Weakness analysis (Weaknesses)

Weaknesses are things from within the company that can hinder business development, for example lack of resources, expertise, management capabilities, funding sources and others.

3. Opportunity Analysis (Opportunities)

Opportunity is a good situation from the corporate environment that can provide benefits to the company. Opportunities are certain market identities, competitive conditions, future demand conditions, regulations, technological changes and increased relationships with consumers or with suppliers providing opportunities to entrepreneurs.

4. Threat Analysis ( Threats )

Threat is a situation that is expected in the company environment which can hamper the company's ability to develop its business. This threat can be in the form of new rival entry, 
slow market growth, rising bargaining power from consumers or suppliers, technological changes or regulations that can pose a threat to success.

\section{IMPLEMENTATION PLAN}

In this simple study, the author designed a communication strategy as an effort to socialize the new logo and the expansion of the TATV coverage area. Meanwhile, the steps in implementing this communication program are as follows:

\section{Promotion}

Promotion is one form of socialization. Campaign activities and program socialization to be carried out, in order to get attention and support from all parties involved and the entire community (target). In this activity, TATV will create a program aimed at building awareness of the public and stakeholders regarding the socialization of new logo changes and coverage areas. This activity will be named "CREATIVE PROMO TV TA". This activity is a TATV roadshow event to several regions in Central Java, on a regular basis. There are several strategic points chosen to attract audiences to join this event. Promotional activities in this case can be done through:

a. An outdoor event which is also aired on-air, was held in several regional centers in the Central Java region, where there will be a public market with various entertainments that attract people to crowded the area. In this event the TATV new logo will be socialized. The location chosen for the implementation of this activity is the city centers, so that it will allow many audiences to visit the activity.

b. Visits to several stakeholders related to TATV, both local government and other sponsors. This visit is to establish closeness with the parties related to TATV.

c. Extending promotional networks is also carried out through collaboration with various other print and electronic media, such as radio, in new coverage areas with the aim of attracting the attention of every community (target audience), contained in the ad campaign by using elements known as AIDDA abbreviations which includes; Attention (attention), Interest (interest), Desire (needs / desires), desation (Decision), and Action (action).

d. Promotion by posting banners for institutional or organizational programs that are stretched / installed on every street or strategic places. Because the banner is usually read at a glance, then the arrangement of the words must be short, solid, clear and will be better if a certain slogan is created so it's easy to remember.

\section{Education}

Education is an educational activity, knowledge provision, or training that is informative, instructive, and persuasive to every community (target audience) so that their knowledge of the institution or organization program increases. Education is a means for TATV to build imagery with various intellectuals. 
Educational activities can be realized by collaborating with various educational institutions, such as universities or vocational high schools in Central Java. Through this education, it is hoped that every investigator / funder will realize their meaning and function in the social order.

This form of collaboration will benefit both parties, first, the need for practical application by formal institutions can be fulfilled. Second, from the financial side and image formation for TATV will also be realized.

\section{Support Raising}

The success of a planning program will work if various related parties support it. A program or activity whatever its shape will work well in accordance with what is expected if there are adequate supporting factors. One of these factors is the support of various parties. To be able to get support from various parties there needs to be a support or mobilization movement.

In this program, the main goal of raising support and mobilization is to introduce a new TATV program, and strive for the full support and participation of every community (target audience) and government related to the work programs that will be implemented.

One way to raise support is to provide an understanding of all elements of the community both government and private about the existence of the new TATV coverage area logo. This understanding also explains the implications of positive changes that occur when two things happen. There are several forms of support movement that are carried out to obtain support from the community, namely:

a. Holding outdoor activities that invite many people

b. Take advantage of strategic moments.

\section{Action and Penetration}

After determining and defining the program, the next action is to take action on the communication / campaign activities that have been planned previously. There are several steps taken in running the program that is:

a. The promotion stage as described previously is the main goal is to attract interest / attention to the target.

b. The stage of delivering informative, educative, and persuasive messages to the target audience as described in the previous discussion.

c. Stage of consolidation and feedback evaluation.

After determining the form of the action stage, the next action is penetration. Penetration is a breakthrough step in arousing the attention and enthusiasm of the target audience to participate in the campaign. This penetration is also a breakthrough in fostering awareness of each target audience through the approach of beliefs, values, norms, and customs adopted by the target audience so that they can actively participate in the success of the programs held. 


\section{EVALUATION PLAN}

One part of the distinctive characteristics of good organizational management is conducting an evaluation of each activity program that has been running. By evaluating an activity you will find out the weaknesses and strengths, it has. Evaluation is a method of reviewing and evaluating the success of communication / campaign activities that have been carried out, with the aim of improving or increasing the success that has been achieved previously.

Evaluation activities can be carried out starting from previously set goals, whether achieved or not, or whether the level of achievement is high or low. In conducting the evaluation, it is done by following the steps as follows:

1. Prepare data collection tools, in either the form of research instruments or other things related to the campaign.

2. Establish a data collection system so that data is collected from the time of preparation, during the process (feedback), and after completing a series of campaign activities.

3. Data collection, collected through direct observation to the field (target audience) through interviews and questionnaires.

4. Data analysis is the most important activity in the evaluation, because the accuracy of the data and interpretation of the data will influence subsequent policies.

5. In addition, the evaluation process is carried out by adjusting the standards that have been set with the results achieved from each element of the activity. More details of evaluations in an organization or organization program campaign are carried out through several levels of evaluation:

6. The initial evaluation was carried out after the conceptualization stage to see the final preparation before the operational communication process was carried out. Evaluations at this stage include; readiness of communication channel facilities, readiness of communication materials, readiness of communicator staff, and readiness of other related matters.

7. Mid evaluation, divided in two, first done after the campaign stage by looking; community response and public interest. Second, it is done after the period of implementation / adoption is carried out. Evaluation of this stage is done to see the adoption target that has been carried out by the target in accordance with the time specified or not.

8. Final evaluation, conducted at the end of the activity period. In this phase an evaluation process is carried out to see the whole program, whether it is in accordance with the goals and targets set. Evaluation activities will be followed by surveys in all regions that have been designated as targets. The results of this evaluation will also be used as feedback to develop the next program.

\section{INSTITUTION}

In the new TATV logo and coverage change socialization program, it is necessary to maintain all existing activities by holding sustainable activities from region to region, so that the community continues to have a brand about TATV. 
Part or the maintenance team brand TATV appointed by the company is part of D ivisi Reporting and Marketing Division also public relations firm course. Both these divisions and the public relations department of the company have the responsibility to innovate and create new creations in campaign messages in an effort to increase the awareness of the target audience. This is done to eliminate boredom for communicators and communicants.

The maintenance and stabilization team also functions to foster the quality and quantity of continuous communication networks with various other related parties, through the submission of reports, so that both moral and material support is not broken until the goal is achieved optimally. In addition to communicating through reporting, it also communicates directly through face to face.

\section{References}

Aji, Firman B. 1990. Planning and Evaluation: A System for Development Projects. Jakarta : Bumi Aksara

Alex S. N. (1989). Management of a Foundation and Introduction. Jakarta : Ghalia Indonesia Brannan, T. (1998). Integrated Marketing Communication, Jakarta: Gramedia

Eddy C.Y. (1994). Communication Policy and planing in Singapore . Happened. Nirwono . Jakarta : LP3ES

Gregory, A. (2003). Planning and Managing A Public Relations Campaign. New Delhi. Crest Publishing House.

Harjana, A. (2000). Communication Audit. Jakarta: Grasindo

Kotler, P. (1994). Marketing Management. The Millennium Edition . USA: The Prentice Hall International.

Muktiyo, W. (2006). Building a Business with the Power of Image. Surakarta: Pine

Smith, D. R. (2005). Strategic Planning For Public Relations. ( $2^{\text {nd }}$ ed.). London: Lawrence Erlbaum Associates Publisher.

Suyanto, M. (2005). Television Advertising Planning Strategy. Andi Yogyakarta.

Tanri A. (1987). Management in Perspective. Yogyakarta: LMP2M (Institute for Research and Community Service Management ) BPFE

Tjiptono, C., \& Adriana. (2008). Strategic Marketing. Yogyakarta: Andi Offset

Wahyuni, A. S. (1996). Strategic Management: An Introduction to the Strategic Thinking Process. Jakarta: Binarupa Aksara.

Widjaya, A.W. 1(987). Planning As a Function of Management. Jakarta: PT. Bina Aksara 